9. Shulha I. M. Vplyv gendernykh nastanovlen vchytelia na formuvannia valeolohichnoi kultury molodshykh shkoliariv [The Influence of Teacher' Gender Attitudes in Forming of Valeological Culture of Junior Students]. Naukovi zapysky TNPU. Seria pedahohika. 2015. № 1. S. 124-130.

УДК 371:343:85

DOI 10.25128/2415-3605.20.2.26

\title{
IВАННА ПАРФАНОВИЧ
}

orcid.org/0000-0002-5300-7092

parfanovichi@ukr.net

доктор педагогічних наук, доцент

Тернопільський національний педагогічний університет імені Володимира Гнатюка вул. Максима Кривоноса, 2, м. Тернопіль

\section{ФАКТОРИ ВПЛИВУ НА ПРОФЕСІЙНЕ ВИГОРЯННЯ ФАХІВЦІВ СОЦІАЛЬНОЇ СФЕРИ}

Розглянуто професійне вигоряння, щзо трактується як неспроможність виконувати професійні обов'язки на належному рівні внаслідок тривалого фізичного та/чи психічного перевантаження. Основний зміст дослідження полягає у визначенні можливостей профілактики професійного вигоряння фахівия сочіальної сфери задля забезпечення його фізичного й психічного здоров'я. Представлено думки науковців щзодо актуальності, мети, поліаспектності, змісту, об'єктивного і суб'єктивного чинників, відмінностей організаційного і психолого-педагогічних складових профілактики. Обтрунтовано вплив на професійну діяльність суспільних норм, иінностей, особистої відповідальності. Визначено показники колективного неблагополуччя, що мають значення у професійному вигорянні індивіда як члена колективу. До експериментального дослідження залучено осіб, котрі не зазнали професійного вигоряння, та осіб, котрі пережили стан професійного вигоряння - для порівняння. Доведено статистичними показниками, що особи, які пережсли стан професійного вигоряння, мають значно глибші психоемоційні порушення, змішення у мотивації професійної діяльності, деформацію ставлення до виконання професійних обов'язків. Наведено оцінювання наявних ризиків професійного вигоряння фахівцями різних сочіальних структур. На основі статистичних показників виділено віктимні групи, підхід у профілактичній роботі до кожної з яких застосовується диференційовано. 3'ясовано, що професійне вигоряння зумовлене різними факторами, серед яких основні: сочіально-економічні загальносуспільні детермінанти; законодавче й нормативно-організачійне забезпечення прочесу прачі; сочіальні й організачійні умови функціонування колективу; індивідуальні та особистісні якості особистості; стресостійкість; мотивачія діяльності; відповідність якостей і рис особистості вимогам обраної професії, професійна компетентність; здатність праџювати у колективі, вміння враховувати думки $i$ позиції інших, комунікабельність; наявність життєвого, професійного досвіду; психологічна сумісність окремих членів колективу; вміння контролювати ситуацією в колективі з боку керівництва; корпоративна культура, наявність спільних інтересів $і$ заходів, зацікавленість у розвитку й прочвітанні колективу. Теоретичним аналізом ци експериментальним дослідженням проблеми професійного вигоряння засвідчено наявність ризиків у професійній діяльності фахівців різних сочіальних структур.

Ключові слова: професійна діяльність, професійне вигоряння, фахівці соціальної сфери, збереження здоров'я, профілактика.

\section{ИВАННА ПАРФАНОВИЧ}

доктор педагогических наук, доцент Тернопольский национальный педагогический университет имени Владимира Гнатюка, ул. Максима Кривоноса, 2, г. Тернополь

\section{ФАКТОРЫ ВЛИЯНИЯ НА ПРОФЕССИОНАЛЬНОЕ ВЫГОРАНИЯ СПЕЦИАЛИСТЫВ СОЦИАЛЬНОЙ СФЕРЫ}

Рассмотрено профессиональное выгорание, которое рассматривается как неспособность выполнять профессиональнье обязанности на должном уровне вследствие длительного физического 
и/или психического утомления. Основное содержание исследования заключается в определении возможностей профилактики профессионального выгорания специалиста сочиальной сферы для обеспечения его физического и психического здоровья. Представлены мнения ученых относительно актуальности, цели, полиаспектности, содержания, объективного и субъективного факторов, различий организачионного и психолого-педагогических составляющих профилактики. Обосновано влияние на профессиональную деятельность общественных норм, иенностей, личной ответственности. Проведенным анкетированием спечиалистов соииальной сферы установлены статистические данные, касающиеся факторов влияния на профессиональное выгорание, а также их динамику. Определень показатели коллективного неблагополучия, имеющие значение в профессиональном выгорании индивида как члена коллектива. К экспериментальному исследованию привлечены лица, которые не испытали профессионального выгорания и лии, переживших состояние профессионального выгорания для сравнения. Доказано статистическими показателями, что лица, пережившие состояние профессионального выгорания, имеют более глубокие психоэмочиональные нарушения, смещение в мотивации профессиональной деятельности, деформацию отношения к выполнению профессиональных обязанностей. Проведена оченка имеющихся рисков профессионального выгорания среди специалистов различных сочиальных структур. На основе статистических показателей выделены виктимные группы, подход в профилактической работе к каждой из которых применяется дифферениированно. Выяснено, что профессиональное выгорание обусловлено различными факторами, среди которых основные: сочиальные и организачионные условия функиионирования коллектива, законодательное и нормативноорганизационное обеспечение прочесса труда; индивидуальные и личностные качества индивида, стрессоустойчивость, мотивачия деятельности; соответствие качеств и черт личности требованиям выбранной профессии, профессиональная компетентность; способность работать в коллективе, умение учитывать мнения $u$ позиции других, коммуникабельность; наличие жизненного, профессионального опыта; психологическая совместимость отдельных членов коллектива; умение контролировать ситуачией в коллективе со стороны руководства; корпоративная культура, наличие обших интересов и мероприятий, заинтересованность в развитии и проиветании коллектива. Теоретическим анализом и экспериментальным исследованием проблемы профессионального выгорания засвидетельствовано наличие рисков в профессиональной деятельности спечиалистов различньх сочиальных структур.

Ключевые слова: профессиональная деятельность, профессиональное выгорание, спечиалисты соииальной сферы, сохранение здоровья, профилактика.

\section{IVANNA PARFANOVICH}

Doctor of Pedagogical Sciences, Associate Professor Ternopil National Pedagogical University named after Vlodimir Hnatiuk, 2 Maksym Kryvonis Str., Ternopil

\section{FACTORS INFLUENCING THE PROFESSIONAL BURNOUT OF SOCIAL WORKERS}

The article is devoted to the study of burnout, which is interpreted as the inability to perform professional duties at the proper level due to prolonged physical and/or mental overload. The main content of the study is to determine the possibilities of prevention of professional burnout of a social worker in order to ensure his physical and mental health.Scientific opinions and positions on the relevance, purpose, multifaceted nature, content of prevention, objective and subjective factors of prevention, differences in organizational and psychological and pedagogical influences of prevention, the specifics of social prevention and prevention. As well as the impact on the professional activities of social norms and deviations from norms, values, responsibilities. The causes of burnout can be differentiated by the nature of the determination. Among the main groups of determinants - social, medical, biological, psychological. The conducted survey among social specialists on the state of professional burnout revealed certain tendencies and regularities among them. This was evidenced by statistics relating to the factors influencing the professional burnout of the specialist, as well as their dynamics. The basis of professional activity should be to provide conditions for this.

However, collective life, in addition to having advantages, is also endowed with negative features. Indicators of collective distress that have a direct impact on the professional burnout of an individual member of the team are identified. These include problems and / or lack of corporate culture; dissatisfaction with the psychological atmosphere prevailing in the team; presence of conflict situations, quarrels, intrigue; absence or problems of interpersonal communication in the team, division into groups; low level of mutual assistance and support, unwillingness to maintain friendly relations; no punishment for guilt, reaction to negative behavior of colleagues, control over subjective factors; lack of prospects for team development; lack of conditions for 
personal development and formation; lack of measures to prevent occupational burnout. For comparison, the experimental study involved people who did not suffer from burnout and people who survived the state of burnout.

Thus, people who have experienced a state of burnout have much deeper psycho-emotional disorders. Their professional experience is characterized by significant negative experiences and beliefs. Positive corporate social ties have been disrupted in their lives, which can lead to disruption in other areas: family, personal, spiritual and emotional. That is, it causes a number of other shifts. Certain trends are evidenced by statistics on the assessment of the existing risks of burnout, which concern specialists in various fields: almost all recognized the fact of burnout to varying degrees; the vast majority of respondents assess the ability to perform professional duties generally well, but the lack of an absolute answer also indicates the risks involved; mostly the presence of risks of burnout is assessed indirectly. On the basis of statistical indicators of occupational burnout, their dynamics can be distinguished victim groups. Given the classification of propensity to burnout, prevention technologies can be used. In each of the three cases, the approach will be different. It is established that a special place is occupied by the subjective factor of professional activity.

Professional burnout is caused by various factors: social and organizational conditions of functioning of collective, legislative and normative-organizational maintenance of process of work; individual and personal qualities of personality, stress resistance, motivation of activity; compliance of qualities and personality traits with the requirements of the chosen profession, professional competence; ability to work in a team, ability to take into account the opinions and positions of others, sociability; availability of life, professional experience; psychological compatibility of individual team members; ability to control the situation in the team by management; corporate culture, the presence of common interests and activities, interest in the development and prosperity of the team. Theoretical analysis and experimental study of problems related to burnout indicate the presence of risks in the professional activities of professionals from different social structures. That is, it depends not so much on objective factors as on the subjective attitude of the individual to himself and his mental and physical health. And the problem looks not so much psychological as psychological and pedagogical.

Keywords: professional activity, professional burnout, social specialists, health preservation, prevention.

У найбільш загальному вигляді життєдіяльність людини пов'язана з сімейною сферою та професійною зайнятістю. Особливе місце займає сфера професійної діяльності, яка $\epsilon$ визначальним фактором соціалізації, добробуту, самопочуття. Нераціональний підхід до організації роботи часто призводить до професійного вигоряння. Особливо це є актуальним у роботі психологічного характеру з людьми. Наслідком перенапруження можуть бути проблеми 3 фізичним і психічним здоров'ям. Соціальна, соціально-педагогічна, соціально-психологічна діяльність має зазначені ризики.

Якщо підходити до поняття «професійне вигоряння», то узагальнено [2, с. 40; 4, с. 12] можна констатувати його як неспроможність виконувати професійні обов'язки на належному рівні внаслідок тривалого фізичного та/чи психічного перевантаження. Основною метою профілактики професійного вигоряння $є$ забезпечити дотримання індивідом норм у ставленні до себе і свого здоров'я, передбачених можливостями суспільного укладу і відносин. Констатується, що особи, які пережили стан професійного вигоряння, мають певні відмінності у поведінці. Вони стають замкненими в собі, віддаленими від суспільних реалій. Іноді це набуває характеру дивакуватості, надмірної агресивності, ексцентричності. Опосередкований негативний вплив полягає в тому, що не реалізуються здібності, задатки людини. Протидії цьому немає через відсутність впливу формальних колективів, формування культури міжособистісних стосунків, розвиток позитивних нахилів, здібностей, інтересів [2, с. 39]. Інформаційне перенасичення, психологічна перевтома людини і перевантаження становлять основу погіршення психічного, тому й зростає актуальність профілактики таких негативних явищ.

Констатація факту професійного вигоряння свідчить про неправильно визначені особистісні цінності як орієнтири життєдіяльності людини. Оскільки особистісні цінності формуються на основі соціальних, зроблено такі узагальнення щодо їх сутності та значення: це соціальний феномен, який існує в діалектичному сенсі суб'єкт-об'єкт; важливий фактор, що стимулює поведінку і вчинки особи та соціальних груп; цінності визначають ставлення людини до світу, самої себе, спрямовують іï розвиток [12, с. 171-173]. Життя людини та їі здоров'я визначено як найголовніші суспільні цінності. І особливо це стосується професійного вигоряння відповідно до динамічних умов суспільного розвитку, коли існують екологічне забруднення, відсутність фізичної активності як фону для фізичного здоров’я людини. 
Метою статті $є$ визначити сутність, значення і можливості профілактики у професійному вигорянні фахівця соціальної сфери задля забезпечення фізичного та психічного здоров'я.

В основі профілактики має бути здатність обрати певну лінію поведінки, самостійно формулювати моральні обов'язки, вимагати від себе їх виконання, здійснювати самооцінку, самоконтроль [8, с. 18]. Зазначається багатоаспектність профілактики: «Якщо ми хочемо попередити відхилення у розвитку й поведінці особистості, то повинні перш за все створити такі умови, при яких охоплено було би всі сторони життєдіяльності, що є невіддільною частиною всього буття соціуму, проникнення в усі сфери суспільних відносин» [11, с. 41]. Отже, профілактику професійного вигоряння (попередження, запобігання) варто розглядати як цілеспрямований процес організації і здійснення комплексу профілактичних заходів, спрямованих на забезпечення соціально-психологічного розвитку і життєдіяльності [10, с. 212].

Н. Лавриченко зауважує, що суб'єкт соціального життя і діяльності має змогу піднестися до рівня культури, досягнутого суспільством у ході тривалої його еволюції, і в цьому сенсі прирівнятись до нього і стати в ньому своїм [6, с. 9]. Суб'єктивність профілактики полягає у ціннісному орієнтуванні індивіда або в дотриманні соціальних норм, що відповідають соціальним цінностям. Це має бути основою підходу до професійної діяльності, а у профілактиці професійного вигоряння це передбачає визначення такої лінії поведінки, яка б забезпечила високий рівень життєдіяльності.

Професійне вигоряння є наслідком порушення норм поведінки. Критеріями відхилень від норми виділяють: а) статистичний (норма для будь-якого явища шляхом підрахунку частоти, 3 якою вона зустрічається); б) якісно-кількісна оцінка поведінки (за ступенем вираження та рівнем загрози для життя); в) психопатологічний (медичний); г) соціально-нормативний (рівень соціальної адаптації індивіда) [4, с. 11]. Причиною професійного вигоряння може бути i гіпервідповідальність людини як члена колективу. Вирізняють чотири типи відповідальності: інтегральну (загальнолюдські норми і вимоги суспільства стали для індивіда особистісно значущими), групову (орієнтація на референтну групу, на досягнення вузькогрупових цілей), вузькоособисту (орієнтовану на особисті, корисливі інтереси), невизначену (або несправжню, удавану). Аналогічно до типів соціальної відповідальності вирізняють чотири групи асоціальної [3, с. 3]. У такому ракурсі необхідно розглядати зв'язок віктимної і девіантної поведінки [10, с. 109]. Отже, професійне вигоряння залежить передусім від відповідального ставлення до себе самого суб'єкта професійної діяльності.

Причини професійного вигоряння можна диференціювати за характером детермінації:

- пояснюють неправильну поведінку негативною соціальною реакцією, стигматизацією, тобто, соціальні групи застосовують ці правила до окремих індивідів і наклеюють на них ярлик аутсайдерів, а девіантом $€$ той, на кого вдалося наклеїти цей ярлик [1];

- серед детермінант, що впливають на ставлення до себе i професійної діяльності, виділяють ті, що лежать в основі статевого диморфізму, стану здоров'я, самопочуття, захворювань, зокрема, враховуються деякі біологічні чинники, які можуть негативно впливати на психіку, що призводить до неадекватної поведінки [5, с. 115];

- широке коло проблем зумовлює екологічне забруднення довкілля; це має наслідки у погіршенні фізичного, а відтак і психічного здоров'я, підвищенні агресивності, зниженні впевненості у собі, зростанні рівня тривожності, кількості пережитих стресів і посиленні дії стресових чинників (є свідчення про дезадаптаційний вплив погіршення співвідношення екологічної якості міського середовища з біологічними потребами людини [7, с. 22];

- серед психологічних детермінант, що призводять до професійного вигоряння, називають агресію, агресивність у стосунках людей; різні підходи до пояснення агресивності аналізує Р. Охрімчук $[9$, с. $4-7]$.

Фахівці соціальної сфери - це переважно жінки. Оскільки сьогодні особи жіночої статі дедалі частіше заявляють про свою рівноправність, на них покладено багато обов'язків і вдома, i на роботі. Проте це часто призводить до психічного перевантаження людини і прояву неврозів. Щоб уникнути відхилень, потрібно вміти регулювати свої бажання, породжені суспільною думкою, і можливості, які дає нам фізичний та/чи психічний ресурс організму. Соціальна стратифікація, що панує у суспільних відносинах, створює перенапруження, коли людина прагне досягти більшого дорогою ціною здоров'я. Крім того загальновідомо, що рівень 
навантаження неоднаковий серед різних вікових груп населення, чоловіків і жінок, людей різних професій.

Нами проведено анкетування серед фахівців соціальної сфери щодо стану професійного вигоряння серед них. Взято до уваги відповіді 22 респондентів, які працюють на посадах в органах державної виконавчої влади і місцевого самоврядування (м. Тернопіль, Тернопільська область).

У табл. 1 наведено статистичні дані стосовно факторів впливу на професійне вигоряння фахівця, а також їх динаміка.

Таблиия 1

Фактори і динаміка впливу на професійне вигоряння (за свідченнями фахівиів соиіальної сфери)

\begin{tabular}{|c|c|c|c|}
\hline Професійні компоненти & $\begin{array}{l}\text { Значний вплив } \\
(\%)\end{array}$ & $\begin{array}{l}\text { Посередній } \\
(\%)\end{array}$ & $\begin{array}{r}\text { Незначний } \\
\text { вплив (\%) }\end{array}$ \\
\hline Характер роботи & 21,2 & 42,0 & 36,8 \\
\hline $\begin{array}{lc}\text { Tерміни } & \text { виконання } \\
\text { професійних обов'язків }\end{array}$ & 42,6 & 34,6 & 22,8 \\
\hline $\begin{array}{l}\text { Внутрішньо- колективні } \\
\text { стосунки }\end{array}$ & 63,4 & 21,4 & 14.8 \\
\hline $\begin{array}{l}\text { Професійна здатність } \\
\text { виконувати обов'язки }\end{array}$ & 63.4 & 12,6 & 23,0 \\
\hline
\end{tabular}

Наведені статистичні дані переконують, що внутрішньоколективні стосунки і здатність виконувати професійні обов'язки найбільше впливають на психоемоційний стан особи та рівень ії професійного вигоряння.

Відмінності організаційного i психолого-педагогічних впливів профілактики проявляються щодо змісту понять «соціальна профілактика» і «превенція». На відміну від соціальної профілактики, превенція - це сукупність психолого-педагогічних заходів стосовно індивіда, що здійснюються з метою попередження негативних явищ і ситуацій, соціальнопсихологічних проблем, зміщень у розвитку, життєдіяльності, поведінці особи. Превенція у межах системи профілактики охоплює як педагогічний, так і психологічний аспекти [10, c. 212]. Це засвідчує, що мають значення як соціально-організаційна, так і психологопедагогічна складова профілактики. Отже, в основі професійної діяльності має бути забезпечення умов для цього. Проте колективна співпраця, крім того, що має переваги, наділена і негативними рисами. У табл. 2 представлено ті показники колективного неблагополуччя, що безпосередньо впливають на професійне вигоряння індивіда як члена колективу.

Таблиия 2

Порівняльний аналіз показників колективного неблагополуччя, що впливають на професійне вигоряння

\begin{tabular}{|l|l|c|c|}
\hline $\begin{array}{l}\text { № } \\
\text { 3н/п }\end{array}$ & $\begin{array}{c}\text { Особи, які не } \\
\text { зазнали } \\
\text { професійного } \\
\text { вигоряння (\%) }\end{array}$ & $\begin{array}{c}\text { Особи, які } \\
\text { пережили стан } \\
\text { професійного } \\
\text { вигоряння (\%) }\end{array}$ \\
\hline 1. & $\begin{array}{l}\text { Проблеми та/чи відсутність корпоративної } \\
\text { культури }\end{array}$ & 16,7 & 65,3 \\
\hline 2. & $\begin{array}{l}\text { Невдоволеність психологічною атмосферою, яка } \\
\text { панує в колективі }\end{array}$ & 42,5 & 88,8 \\
\hline 3. & $\begin{array}{l}\text { Наявність конфліктних ситуацій, сварок, } \\
\text { інтриганства }\end{array}$ & 15,4 \\
\hline 4. & $\begin{array}{l}\text { Відсутність чи проблеми міжособистісного } \\
\text { спілкування в колективі, поділ на групи }\end{array}$ & 25,8 & 74,9 \\
\hline 5. & $\begin{array}{l}\text { Низький рівень взаємодопомоги і підтримки, } \\
\text { небажання підтримувати дружні стосунки }\end{array}$ & 34,2 & 96,3 \\
\hline 6. & $\begin{array}{l}\text { Відсутність покарань за провини, реагування на } \\
\text { негативну поведінку колег, контролю 3а } \\
\text { суб'єктивними чинниками }\end{array}$ & 30,1 & \\
\hline
\end{tabular}


ОБГОВОРЮЄМО ПРОБЛЕМУ

\begin{tabular}{|l|l|c|c|}
\hline 7. & Відсутність перспектив розвитку колективу & 14,8 & 67,7 \\
\hline 8. & $\begin{array}{l}\text { Відсутність умов особистісного розвитку й } \\
\text { формування }\end{array}$ & 45.8 & 95,5 \\
\hline 9. & $\begin{array}{l}\text { Відсутність заходів профілактики професійного } \\
\text { вигоряння }\end{array}$ & 33,4 & 77,5 \\
\hline
\end{tabular}

Так, особи, які пережили стан професійного вигоряння, мають значно глибші психоемоційні порушення. Їх професійний досвід характеризується значними негативним досвідом і переконаннями. У їхному житті зазнали деформації позитивні корпоративні соціальні зв'язки, що може призвести до відхилень в інших сферах: сімейній, особистісній, духовно-емоційній. Тобто це викликає і інші деформації. Названі компоненти рівноваги становища особи базуються на відсутності єдиної основи - тепла, довіри, любові, уваги, турботи, підтримки, піклування, взаєморозуміння. Не знайшовши їх, людина черствіє, стає байдужою не тільки до своїх проблем, переживань, а й до відчуттів інших людей.

Втрата життєвих орієнтирів, відсутність позитивних емоцій, душевна черствість 3 часом

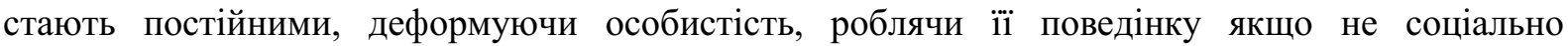
небезпечною, то неадекватною. Компенсацією позитивних емоцій у життєдіяльності часто стають адиктивні прояви: пияцтво, алкоголізм, наркоманія, тютюнопаління, інтернетзалежність, комп’ютерна залежність, ігрова залежність та інші види адикцій.

У табл. 3 наводимо статистичні дані щодо оцінювання наявних ризиків професійного вигоряння фахівцями різних соціальних структур для порівняння.

Таблиия 3

Розподіл відповідей фахівців сочіальної сфери щэодо оцінювання наявних ризиків професійного вигоряння

\begin{tabular}{|c|c|c|c|c|}
\hline \multicolumn{5}{|c|}{ Фахівці соціальної сфери } \\
\hline $\begin{array}{c}\text { Працівники } \\
\text { центру } \\
\text { соціальних служб } \\
(\%)\end{array}$ & $\begin{array}{c}\text { Працівники } \\
\text { відділу } \\
\text { у справах сім’і } \\
\text { та молоді (\%) }\end{array}$ & $\begin{array}{c}\text { Працівники } \\
\text { служби у справах } \\
\text { дітей (\%) }\end{array}$ & $\begin{array}{c}\text { Працівники } \\
\text { центру } \\
\text { зайнятості } \\
\text { населення (\%) }\end{array}$ & $\begin{array}{c}\text { Педагоги } \\
\text { загально } \\
\text { освітньої } \\
\text { школи (\%) }\end{array}$ \\
\hline 18 & 21 & 20 & 26 & 24 \\
\hline 55 & 58 & 64 & 48 & 54 \\
\hline 22 & 21 & 8 & 24 & 22 \\
\hline 5 & - & - & 2 & - \\
\hline
\end{tabular}

Як видно з табл. 3:

- майже всі, крім 8 осіб, визнали факт професійного вигоряння різного ступеня;

- переважна більшість респондентів оцінює здатність виконувати професійні обов'язки переважно добре, проте відсутність абсолютної відповіді також свідчить про наявні ризики;

- переважно наявність ризиків професійного вигоряння оцінюють посередньо.

На основі теоретичного аналізу [10, с. 112-113], статистичних показників професійного вигоряння, їх динаміки можна виділити віктимні групи:

1 група - завдяки правильному орієнтуванню та спрямованості поведінки, здоровому способу життя їм не загрожує професійне вигоряння; позитивним $є$ те, що вони бачать своє майбутнє, шляхи розвитку кар'єри і готові добиватися своєї мети, не зупиняючись до досягнутому, прагнуть бути щасливими і бажають цього іншим;

2 група - їх становище, поведінка і спосіб життя не сприяють правильній соціалізації, збереженню і зміцненню здоров'я, існує загроза соціальних і психічних зривів; але ще можна змінити поведінку, звички, спосіб життя; особа потребує уваги і піклування;

3 група - під дією постійних віктимних факторів їхня поведінка і спосіб життя $є$ неадекватними, асоціальними чи спрямованими на руйнування власного здоров'я i життя, а також інших людей. 
3 огляду на наведену класифікацію схильності до професійного вигоряння застосовувати технології профілактики варто з урахуванням наявного ступеня психологічного вигоряння особи. У кожному з трьох випадків підхід буде диференційованим.

Професійне вигоряння зумовлене різними факторами, серед яких на основі опитування, статистичних даних, експертного оцінювання проведеного експериментального дослідження можна виокремити такі:

- соціальні й організаційні умови функціонування колективу, законодавче й нормативноорганізаційне забезпечення процесу праці;

- індивідуальні та особистісні якості особистості, стресостійкість, мотивація діяльності;

- відповідність якостей i рис особистості вимогам обраної професії, професійна компетентність;

- здатність працювати у колективі, вміння враховувати думки i позиції інших, комунікабельність;

- наявність життєвого, професійного досвіду;

- психологічна сумісність окремих членів колективу;

- вміння контролювати ситуацією в колективі з боку керівництва;

- корпоративна культура, наявність спільних інтересів і заходів, зацікавленість у розвитку й процвітанні колективу.

Теоретичний аналіз та експериментальне дослідження проблем щодо професійного вигоряння свідчать про наявність ризиків у професійній діяльності фахівців різних соціальних структур. Тобто це залежить як від об'єктивних факторів (суспільні негаразди), так і від суб'єктивного ставлення індивіда до себе і свого психічного та фізичного здоров'я: від того, як налаштовує себе фахівець, його мотивація і вміння організувати правильно себе, свій життєвий простій, власну діяльність.

Надалі варто приділити увагу тому, що це проблема не тільки суспільна, колективна, а й індивідуальна. Потребує теоретичного аналізу й практична перевірка діагностичного інструментарію, ефективності заходів профілактики стосовно професійного вигоряння індивіда.

\section{ЛIТЕРАТУРА}

1. «Аутсайдеры: исследования по социологии девиантности» - обзор книги Говарда Беккера. URL: https://discours.io/articles/theory/autsaydery-issledovaniya-po-sotsiologii-deviantnosti-obzor-knigigovarda-bekkera

2. Бутенко В., Пономаренко Г. Актуальні проблеми профілактики злочинності серед молоді. Соціально-правовий захист молоді: зб. наук. статей / заг. ред.: І.В.Козубовська, В. М. Великий. Ужгород, 2002. С. 39-47.

3. Гурлева Т. Г. Діагностика та корекція відповідальності у підлітків. Практична психологія та соціальна робота. 1999. № 5. С. $2-4$.

4. Дахно Р. Девіантна поведінка учнів загальноосвітніх навчально-виховних закладів як психологопедагогічна проблема. Рідна школа. 2005. № 11. С. 10-13.

5. Курс кримінології: особлива частина: підручник: у 2 кн. Кн. 2 / М. В. Корнієнко, Б. В. Романюк, І. М. Мелькин та ін.; за заг. ред. О. М. Джужи. К.: Юрінком Інтер, 2001. 480 с.

6. Лавриченко Н. Категорії «соціальність», «духовність» і «моральність» в сучасній педагогічній науці. Шлях освіти. 2003. № 1. С. 7-11.

7. Лактионова Г. М. Крупный город как среда социализации (теоретико-методологический аспект). Соціально-педагогічні та медико-психологічні заходи протидії вживанню наркогенних засобів неповнолітніми і молоддю: наук.-метод. посібник / упоряд. О. І. Пилипенко. К.: А.Л.Д., 1995. C. $16-32$.

8. Оржеховська В. М., Пилипенко О. І. Сучасні орієнтири превентивної педагогіки. Педагогіка і психологія. Вісник АПН України. 2005. № 2. С. 17-25.

9. Охрімчук Р. Багатолика агресія. Початкова школа. 2003. № 6. С. 4-7.

10. Парфанович I. I. Теоретико-методичні засади профілактики девіантної поведінки дівчат загальноосвітніх шкіл: дис. ... д-ра пед. наук: 13.00.05. К., 2014. 478 с.

11. Соціологія: підручник для студ. вищих навч. закладів / за ред. В. Г. Городяненка. К.: Академія, 2005. $560 \mathrm{c}$. 
12. Шандрук С. Формування ціннісних орієнтацій молоді та іiї соціалізація засобами масової інформації. Наукові записки Кіровоградського державного педагогічного університету. Серія. Педагогічні науки. 2001. Вип. 38. С. 169-174.

\section{REFERENCE}

1. «Autsaydery: issledovaniya po sotsiologii deviantnosti» - obzor knigi Govarda Bekkera [The Outsiders: Research on the Sociology of Deviance - a review of Howard Becker's book]. URL: https://discours.io/articles/theory/autsaydery-issledovaniya-po-sotsiologii-deviantnosti-obzor-knigigovarda-bekkera

2. Butenko, V., Ponomarenko, H. (2002). Aktualni problemy profilaktyky zlochynnosti sered molodi [Current issues of crime prevention among young people]. Sotsialno-pravovyi zakhyst molodi: zbirnyk naukovykh statei [Socio-legal protection of youth: a collection of scientific articles]. I. V. Kozubovska, V. M. Velykyi. Uzhhorod. S. 39-47. [in Ukrainian].

3. Hurleva, T.H. (1999). Diahnostyka ta korektsiia vidpovidalnosti u pidlitkiv [Diagnosis and correction of responsibility in adolescents]. Praktychna psykholohiia ta sotsialna robota [Practical Psychology and Social Work]. 5. S. 2-4 [in Ukrainian].

4. Dakhno, R. (2005). Deviantna povedinka uchniv zahalnoosvitnikh navchalno-vykhovnykh zakladiv yak psykholoho-pedahohichna problema [Deviant behavior of teachers of general educational institutions as a psychological and pedagogical problem]. Ridna shkola - Native school, 11, 10-13 [in Ukrainian].

5. Korniienko, M.V., Romaniuk, B.V., Melkyn, I.M. \& O.M. Dzhuzhy (Ed.). (2001). Kurs kryminolohii: osoblyva chastyna [Criminology course: special part]. (Vol. 1-2). Kyiv: Yurinkom Inter [in Ukrainian].

6. Lavrychenko, N. (2003). Katehorii "sotsialnist", "dukhovnist" i "moralnist" v suchasnii pedahohichnii nautsi [Categories "sociality", "spirituality" and "morality" in modern pedagogical science]. Shliakh osvity - The path of education, 1, 7-11[in Ukrainian].

7. Laktionova, G.M. (1995). Krupnyy gorod kak sreda sotsializatsii (teoretiko-metodologicheskiy aspekt) [Large city as a socialization environment (theoretical and methodological aspect)]. Sotsialnopedagogichni ta mediko-psikhologichni zakhodi protidiï vzhivannyu narkogennikh zasobiv nepovnolitnimi i moloddyu -Socio-pedagogical and medical-psychological measures to combat the use of narcotic drugs by minors and youth. O.I. Pilipenko (Ed.), (pp. 16-32). Kyiv: A.L.D. [in Ukrainian].

8. Orzhekhovska, V. M., \& Pylypenko, O. I. (2005). Suchasni oriientyry preventyvnoi pedahohiky [Modern guidelines of preventive pedagogy]. Pedahohika i psykholohiia. Visnyk APN Ukrainy - Pedagogy and psychology. Bulletin of the Academy of Pedagogical Sciences of Ukraine, 2, pp. 17-25 [in Ukrainian].

9. Okhrimchuk, R. (2003). Bahatolyka ahresia [Multifaceted aggression]. Pochatkova shkola - Elementary School, 6, pp. 4-7 [in Ukrainian].

10. Parfanovych, I. I. (2014). Teoretyko-metodychni zasady profilaktyky deviantnoi povedinky divchat zahalnoosvitnikh shkil [Theoretical and methodological principles of prevention of deviant behavior of girls in secondary schools]. Doctor's thesis. Kyiv [in Ukrainian].

11. Horodianenko, V. H. (2005). Sotsiolohiia [Sociology]. Kyiv: Akademiia [in Ukrainian].

12. Shandruk, S. (2001). Formuvannia tsinnisnykh oriientatsii molodi ta yii sotsializatsiia zasobamy masovoi informatsii [Formation of value orientations of youth and its socialization by mass media]. Naukovi zapysky Kirovohradskoho derzhavnoho pedahohichnoho Universytetu. Ser. Pedahohichni nauky Scientific notes of Kirovograd State Pedagogical University. Pedagogical Sciences Series. (Issue 38), (pp. 169-174). Kirovohrad [in Ukrainian].

УДК $316.6(075)$

DOI $10.25128 / 2415-3605.20 .27$

VASILIKI PAPOUTSI

bpapoutsi@yahoo.gr Graduate Student

Ternopil Volodymyr Hnatiuk National Pedagogical University

2 Maxym Kryvonis Str., Ternopil

\section{STRATEGIES OF THE EFFECTIVE CONFLICT MANAGEMENT IN THE EDUCATIONAL ENVIRONMENT}

The problem of communication among the participants of the educational environment occupies one of the leading places in modern pedagogical science. A natural possibility in an educational organization is the 